\title{
Physicochemical and Thermal Characteristics of Onion Skin from Fifteen Indian Cultivars for Possible Food Applications
}

\author{
Narashans Alok Sagar $\left(\mathbb{D},{ }^{1}\right.$ Anil Khar $\mathbb{D}^{\circ},{ }^{2}$ Vikas $\mathbb{D}^{\circ},{ }^{3}$ Ayon Tarafdar $\mathbb{D}^{,},{ }^{4}$ and Sunil Pareek $\mathbb{I D}^{1}$ \\ ${ }^{1}$ Department of Agriculture and Environmental Sciences, \\ National Institute of Food Technology Entrepreneurship and Management, Kundli, Sonipat, Haryana 131028, India \\ ${ }^{2}$ Division of Vegetable Sciences, ICAR-Indian Agricultural Research Institute, New Delhi, India \\ ${ }^{3}$ Department of Food Business Management and Entrepreneurship Development, \\ National Institute of Food Technology Entrepreneurship and Management, Kundli, Sonipat, Haryana 131028, India \\ ${ }^{4}$ Livestock Production and Management Section, ICAR-Indian Veterinary Research Institute, Izatnagar, Bareilly, \\ Uttar Pradesh 243 122, India \\ Correspondence should be addressed to Sunil Pareek; sunil_ciah@yahoo.co.in
}

Received 8 July 2021; Revised 25 July 2021; Accepted 30 July 2021; Published 9 August 2021

Academic Editor: Alessandra Durazzo

Copyright (C) 2021 Narashans Alok Sagar et al. This is an open access article distributed under the Creative Commons Attribution License, which permits unrestricted use, distribution, and reproduction in any medium, provided the original work is properly cited.

\begin{abstract}
Every year tons of onion waste is produced worldwide. The dried outer onion skin contributed up to $70 \%$ of this waste. Outerdried skins of fifteen prominent onion cultivars from India were selected for the study. A comparative study was done for proximate profiling, thermal characteristics, functional grouping, and mineral contents. Skin of cv. "NHRDF Red" contained the highest amount of crude protein $(5.97 \pm 0.15 \mathrm{~g} / 100 \mathrm{~g})$, ash $(12.24 \pm 0.59 \mathrm{~g} / 100 \mathrm{~g})$, and fiber $(8.28 \pm 0.20 \mathrm{~g} / 100 \mathrm{~g})$, whereas cv. "Pusa Red" possessed the highest amount of total fat $(0.47 \pm 0.02 \mathrm{~g} / 100 \mathrm{~g})$ and the maximum carbohydrates $(76.66 \pm 0.56 \mathrm{~g} / 100 \mathrm{~g})$ were found in "Pusa Riddhi." Mineral analysis showed that cv. "NHRDF Red" had the maximum concentration of all 9 minerals along with sulphur content. Fourier transform infrared spectroscopy analysis explored the various metabolites present in each cultivar. The thermal analysis explored cv. "Agrifound Dark Red" as highly thermally stable having 70.98\% residual mass. The lowest Tg temperature range was found between $64.4^{\circ} \mathrm{C}$ and $90.6^{\circ} \mathrm{C}$ for "Agrifound Dark Red." Skin of cv. "NHRDF Red" was reported as the best source of protein, fiber, and minerals, which may be utilized for developing a food product.
\end{abstract}

\section{Introduction}

Onion (Allium cepa L.) is the second most important cultivated horticultural commodity after tomato. Globally, $99,968,016$ tons of onion is produced from an area of $5,192,651$ hectares [1]. China holds the first position in production with $18,122,435$ tons and India is the second producer of onion $(11,936,706$ tons) in the world [1]. Up to $25 \%$ of qualitative and quantitative postharvest losses occurred during storage. Processing of onion has also increased which resulted in huge processing waste. Skin contributes maximum to processing waste. The European Union onion processing industry generates more than 500,000 tons of onion waste annually mainly in the UK, The
Netherlands, and Spain. This has become an environmental problem. The maximum amount of onion skin is generated by industries during peeling. This wasted skin is not suitable as fodder in higher concentrations due to its peculiar aroma [2].

Various studies explored onion skin as a rich source of polyphenols, antioxidants, fructooligosaccharides, and dietary fibers [3-5]. Moreover, onion skin extract has also been reported as an anticarcinogenic, hypocholesterolemic, good cardiovascular agent, and having an antiasthmatic effect $[4,5]$. Onion flavonoids also show antiproliferative activity that can degrade excess polyamine concentration in the body [6]. Hence, onion skin powder may be incorporated into bakery products and bread which are good sources of energy 
and consumed widely as well [7]. Wheat bread was fortified with the addition of $3 \%$ onion skin and it enhanced the antioxidant property of the bread with sensory acceptance [8]. Onion skin can also be utilized for the production of energy. Agricultural waste is the prime source to generate energy and is used as an important fuel after oil, coal, and natural gas worldwide [9]. The scarcity of oil, gas, and coal and the large availability of biomass provide an alternative to the industries for energy generation from biomass. The proper understanding of biomass characterization is essential for its effective utilization [10]. The proximate composition is an important parameter for developing a functional food or nutraceutical product. In addition to this, the thermal properties of onion skins are equally important to produce energy or biogas.

Overall, onion waste has become a disposable problem for onion processing industries because of its huge quantity that consequently creates environmental pollution. However, onion waste has the potential to be used as an active ingredient of a food or nutraceutical product. In this regard, the onion skin from 15 Indian cultivars was studied for the following objectives: (1) determining physicochemical properties, (2) analyzing mineral content and active functional groups, and (3) investigating thermal characteristics. All the parameters were studied to provide a solution to environmental pollution by exploring possible food applications.

\section{Materials and Methods}

2.1. Plant Material and Samples Preparation. Fifteen popular cultivars of onion ("Agrifound Dark Red," "Agrifound Light Red," "Arka Kirthiman," "Bhima Kiran," "Bhima Shakti," "Bhima Shubhra," "Hissar-2," "Hissar-3," "NHRDF Red," "Phursungi Local," "Pusa Madhavi," "Pusa Red," "Pusa Riddhi," "Sukhsagar," and "Udaipur Local") were procured from All India Network Research Project on Onion and Garlic, Division of Vegetable Sciences, Indian Agricultural Research Institute, New Delhi, India. The skin of the cultivars was collected ( $100 \mathrm{~g}$ each) after curing at an open field (20 days). Skins were washed with chlorinated water $(0.5 \%)$ for the complete removal of dust and other impurities. Skins were washed again with distilled water, left open in a porous tray for $10 \mathrm{~min}$ to remove excess water, and then kept in deep freeze (Vestfrost Solutions, Denmark) at $-40^{\circ} \mathrm{C}$ for $24 \mathrm{~h}$. Samples were freeze-dried using a lyophilizer (Mini Lyodel, Delvac Pumps, Chennai, India) with keeping the plate temperature at $-50^{\circ} \mathrm{C}$ with the pressure of 0.039 mbar and the drying process was continued up to $48 \mathrm{~h}$. Freeze-dried skin was grounded using a mixer-grinder (3053 colts, Usha International Ltd., India) for powder formation and stored at $-30^{\circ} \mathrm{C}$ in airtight plastic containers for further use.

2.2. Physicochemical Analysis. Water activity $\left(a_{\mathrm{w}}\right)$ of skin powder was analyzed by a water activity meter (Aqua LabTM-Dewpoint, US). The moisture content of the powder was analyzed by a moisture analyzer (Citizen ${ }^{\circledR}$, India). Crude protein and total fat were estimated by Kjeldahl's method (protein-nitrogen conversion factor 6.25) and the Soxhlet apparatus, respectively [10]. Ash content was obtained by placing $3 \mathrm{~g}$ sample in a muffle furnace at $550^{\circ} \mathrm{C}$ for $3 \mathrm{~h}$; after cooling down, the sample was transferred in a dryer and calculated [11]. Total fiber concentration was estimated by calculating the difference in weights before calcination and after calcination. Each sample was digested with the solutions of sulphuric acid (1.25\%) and sodium hydroxide $(1.25 \%)$ and then the residue was calcined. Carbohydrate content was calculated by the following formula:

$$
\begin{aligned}
\text { Carbohydrate } \%= & 100-\text { moisture content }+ \text { total fiber } \\
& + \text { crude protein }+ \text { total fat }+ \text { ash content. }
\end{aligned}
$$

The total sulphur content was also analyzed by a CHNS analyzer (EURO Elemental Analyzer, Wegberg, Germany). The investigation was subjected to the total oxidation of the sample and complete combustion which changes the sample into $\mathrm{SO}_{2}$ (combustion product). The analysis was carried out according to Benitez et al. [12] with slight modifications. $1 \mathrm{mg}$ sample of onion skin of each cultivar was taken for the analysis and sulfanilamide was used as a reference standard.

2.3. Analysis of Mineral Content. The onion skin powder was taken $(0.5 \mathrm{~g})$ into digestion tubes from each sample. Briefly, $2 \mathrm{~mL}$ of concentrated nitric acid $\left(\mathrm{HNO}_{3}\right)$ was poured into each tube and placed into the digestion block at $150^{\circ} \mathrm{C}$. After digestion, clear solutions were obtained which were used for mineral detection. Mineral concentration was detected by ICP-AES (inductive coupled plasma-atomic emission spectroscopy, Fujitsu Quality Lab Ltd., Japan). Results were expressed in $\mathrm{mg} / \mathrm{kg}$ using external standards of $\mathrm{K}, \mathrm{Ca}, \mathrm{P}, \mathrm{Mn}$, $\mathrm{Na}, \mathrm{Mg}, \mathrm{Fe}, \mathrm{Zn}$, and $\mathrm{Cu}$ [13]. The calculation of adequate intake (AI) and population reference index (PRI) was done using the latest recommendations of the European Food Safety Authority (EFSA) [14]. Additionally, the recommended dietary allowances (RDA) given by the Food Safety and Standards Authority of India (FSSAI) for the minerals were also compared with the results [15].

2.4. Assessment of Functional Groups. The presence of various functional groups was assessed by FTIR (Fourier transform infrared spectroscopy, Agilent Cary 630, US) in transmission mode from 4000 to $600 \mathrm{~cm}^{-1}$ as described by Kumar et al. [16]. The graphs were evaluated by MicroLab FTIR software.

2.5. Thermal Characterization. Mass loss of samples was estimated using TGA Libra (Netzsch, Germany) under nitrogen atmosphere $(60 \mathrm{~mL} / \mathrm{min})$ at the heating rate of $5^{\circ} \mathrm{C} /$ min in the temperature range from $20^{\circ} \mathrm{C}$ to $300^{\circ} \mathrm{C}$ [17]. The sample mass used for each sample was $4.0 \pm 0.1 \mathrm{mg}$. The curves were analyzed by Netzsch Proteus software (version 6.1.10). Phase change with glass transition temperature was obtained by DSC 200 F3Maia (Netzsch, Germany). Sample $(4.0 \pm 0.1 \mathrm{mg})$ mass was packed in a hermetically sealed 
aluminum pan in a nitrogen atmosphere $(60 \mathrm{~mL} / \mathrm{min})$ at the heating rate of $5^{\circ} \mathrm{C} / \mathrm{min}$. The temperature range was taken from $30^{\circ} \mathrm{C}$ to $300^{\circ} \mathrm{C}$ and data analysis was carried out using Netzsch Proteus software (version 6.1.10).

2.6. Statistical Analysis. One-way analysis of variance (ANOVA) was applied for data analysis using IBM ${ }^{\circledR}$ SPSS statistics (version 20). All the samples were carried out in triplicate and the results were presented as mean \pm standard deviation on a dry weight basis. Moreover, the Principal Component Analysis (PCA) was applied to the results of proximate composition and mineral analysis to explore a comprehensive view of data.

\section{Results and Discussion}

3.1. Physicochemical Analysis. Water activity is an essential parameter, which is related to food safety, quality, and shelf life. Skin powder of cv. "Pusa Madhavi" had the highest water activity $(0.40 \pm 0.01)$, while "Agrifound Dark Red," "Arka Kirthiman," "Bhima Shakti," and "Pusa Red" cultivars exhibited the least water activity $(0.09 \pm 0.01)$. This indicates that cv. "Pusa Madhavi" contained excessive water for biological reactions in comparison to other cultivars, while cultivars with the least water activity had the lowest quantity of excess water. There was a significant difference $(p \leq 0.05)$ among cv. "Agrifound Dark Red," "Agrifound Light Red," "Bhima Shubhra," "Hissar-2," "Phursungi Local," "Pusa Madhavi," and "Udaipur Local" but no difference was observed among cv. "Bhima Kiran," "NHRDF Red," "Pusa Riddhi," and "Sukhsagar" (Table 1). Maximum moisture content was found in cv. "Pusa Madhavi" $(13.23 \pm 0.90 \%$ d.b.), while cv. "Pusa Riddhi" possessed the lowest moisture content with $6.27 \pm 0.56 \%$ d.b. Moisture content showed a significant difference $(p \leq 0.05)$ among "Agrifound Light Red," "Bhima Kiran," "Phursungi Local," "Pusa Red," "Pusa Madhavi," and "Pusa Riddhi," whereas cv. "Agrifound Dark Red," "Bhima Shakti," "Hissar-3," "NHRDF Red," "Phursungi Local," and "Sikh Sagar" were found to be at par with each other (Table 1). Compared to the onion bulb slices, Rapusas and Driscoll [18] reported 15.7\% moisture content (wet basis) at $2.23 \pm 0.09 \mathrm{~J} / \mathrm{kg}$ specific heat. In addition to this, Ismail et al. [19] analyzed Egyptian onion skins and found $3 \%$ moisture content on a dry basis. In addition to this, Pereira et al. [20] obtained $9.41 \pm 0.09 \%$ moisture content in dried onion waste. The differences in the fiber content of skin and cultivar types were the main reasons behind the variation in the moisture content. In addition, moisture content also depends upon the water available in the sample and the vapor pressure in the atmosphere [21].

Various studies revealed the proximate composition of onion bulbs $[18,19]$ but there are very few studies available that explore the proximate components of onion skins. Present research for proximate analysis showed that skin of "NHRDF Red" cultivar contained the highest amount of crude protein with $5.97 \pm 0.15 \mathrm{~g} / 100 \mathrm{~g}$ and the lowest concentration was reported in "Udaipur Local" $(3.90 \pm 0.10 \mathrm{~g} /$
$100 \mathrm{~g})$. "Pusa Red" exhibited the highest content of total fat $(0.47 \pm 0.02 \mathrm{~g} / 100 \mathrm{~g})$ among all the cultivars, while the least concentration was found in "Bhima Shubhra" $(0.30 \pm 0.02 \mathrm{~g} /$ $100 \mathrm{~g}$ ). The harvesting conditions and the types of cultivars may impart the difference in protein content. A significant difference $(p \leq 0.05)$ was found among "Bhima Shubhra," "Hissar-3," "Pusa Red," and "Pusa Riddhi" cultivars, whereas "Agrifound Dark Red," "Agrifound Light Red," "Arka Kirthiman," "Bhima Kiran," "Pusa Madhavi," "Pusa Riddhi," and "Sukhsagar" were found to be at par with each other for total fat content (Table 1).

The highest amount of crude fiber was obtained in "NHRDF Red" $(8.28 \pm 0.20 \mathrm{~g} / 100 \mathrm{~g})$, while the lowest crude fiber content $(4.45 \pm 0.44 \mathrm{~g} / 100 \mathrm{~g})$ was recorded in "Pusa Madhavi." There was a significant difference $(p \leq 0.05)$ among "Agrifound Dark Red," "Agrifound Light Red," "Bhima Kiran," "NHRDF Red," and "Pusa Madhavi" cultivars for crude fiber content. The highest ash content $(12.24 \pm 0.59 \mathrm{~g} / 100 \mathrm{~g})$ was recorded in cv. "NHRDF Red" skin and the lowest concentration of ash was reported in cv. "Pusa Riddhi" $(6.88 \pm 0.39 \mathrm{~g} / 100 \mathrm{~g})$. Near approximate concentration $(5.7 \pm 0.3 \mathrm{~g} / 100 \mathrm{~g})$ of ash was reported in dry weight of onion skin waste [22]. "Agrifound Dark Red," "Hissar-3," "Phursungi Local," and "Sukhsagar" were found at par with regard to ash content and a significant difference was found among "Bhima Kiran," "Bhima Shubhra," "Phursungi Local," "Pusa Madhavi," "Pusa Riddhi," and "Pusa Red." The concentration of biomolecules may vary with the cultivar types, soil composition, and harvesting time. Maximum carbohydrate content $(76.66 \pm 0.56 \mathrm{~g} / 100 \mathrm{~g})$ was obtained in cv. "Pusa Riddhi," which was much higher than onion slices $(14.77 \pm 0.04 \mathrm{~g} / 100 \mathrm{~g})$ and the extract of onion bulb $(6.91 \pm 0.02 \mathrm{~g} / 100 \mathrm{~g})$ [18]. The lowest amount of carbohydrate was recorded in "NHRDF Red" cultivar $(64.32 \pm 0.99 \mathrm{~g} / 100 \mathrm{~g})$. A significant difference $(p \leq 0.05)$ was found among cv. "Agrifound Dark Red," "Agrifound Light Red," "Bhima Shakti," "Bhima Shubhra," "NHRDF Red," "Pusa Madhavi," and "Udaipur Local" (Table 1). Majid et al. [23] have analyzed onion bulb powder of sprouted and unsprouted cultivars and obtained $3.087-6.08 \%$ total fibers, $70.74-79.54 \%$ carbohydrate, and $8.57-14.16 \%$ proteins. The proximate analysis showed that the color of skin, that is, whited, light red, red, and dark red, imparted the variations in the proximate composition of cultivars. This study showed that onion skin and bulb powder are comparable for total fibers, total carbohydrates, and proteins. Also, the skin is as important for fiber, carbohydrates, and proteins as bulbs.

The highest sulphur concentration was obtained in the skin of cv. "NHRDF Red" $(8.63 \pm 0.17 \%)$ and lowest in $\mathrm{cv}$. "Agrifound Light Red" (3.48 $\pm 0.24 \%)$, while sulphur was not detected in cv. "Bhima Shubhra" and "Udaipur Local." All the cultivars were significantly different $(p \leq 0.05)$ from each other except "Arka Kirthiman" and "Sukhsagar" which were at par. Previous studies revealed that the outer skin of onion contains the lowest amount $(15.6 \pm 0.6 \mu$ moles $/ \mathrm{g} \mathrm{dw})$ of sulphur compared to its other sections such as inner scale (153.1 $\pm 5 \mu$ moles/g dw), top-bottom (143.8 $\pm 3.3 \mu$ moles $/ \mathrm{g}$ $\mathrm{dw})$, and onion bulb $(121.9 \pm 3.2 \mu$ moles/g dw) [12]. 
TABle 1: Physicochemical composition of onion skin powder of fifteen cultivars.

\begin{tabular}{|c|c|c|c|c|c|c|c|c|}
\hline Cultivar & $\begin{array}{c}\text { Water } \\
\text { activity }\left(a_{\mathrm{w}}\right)\end{array}$ & $\begin{array}{c}\text { Moisture } \\
\text { content (\%) }\end{array}$ & $\begin{array}{c}\text { Crude } \\
\text { protein }(\%)\end{array}$ & $\begin{array}{l}\text { Total } \\
\text { fat }(\%)\end{array}$ & $\begin{array}{c}\text { Crude fiber } \\
(\%)\end{array}$ & $\begin{array}{c}\text { Ash content } \\
(\%)\end{array}$ & $\begin{array}{c}\text { Carbohydrate } \\
(\%)\end{array}$ & $\begin{array}{c}\text { Sulphur } \\
\text { content (\%) }\end{array}$ \\
\hline Red & $0.09 \pm 0.00^{\mathrm{a}}$ & $8.77 \pm 0$ & $5.73 \pm$ & $0.35 \pm$ & $6.53 \pm$ & 9.5 & . & 4.50 \\
\hline $\begin{array}{l}\text { Agrifound Light } \\
\text { Red }\end{array}$ & $0.35 \pm$ & $11.24 \pm$ & $5.83 \pm$ & 032 & bc & 780 & & $4^{\mathrm{d}}$ \\
\hline Arka Kirthiman & $0.09 \pm 0.01^{\mathrm{a}}$ & $10.88 \pm$ & $5.27 \pm 0.31^{\mathrm{e}}$ & $0.35 \pm 0.03^{\mathrm{ab}}$ & $6.96 \pm 0.62^{f}$ & $9.11 \pm 0.14^{\mathrm{c}}$ & $\pm 0.81^{\mathrm{b}}$ & $0.03^{\mathrm{f}}$ \\
\hline Bhima Kiran & $0.13 \pm$ & 7.89 & $4.27 \pm$ & $0.34 \pm 0$ & $5.67 \pm$ & $11.60 \pm 0.46^{\mathrm{gh}}$ & $.57^{\mathrm{de}}$ & 2.87 \\
\hline Bhima Shakti & $0.09 \pm 0.00^{\mathrm{a}}$ & $8.79 \pm 0.44^{\mathrm{bc}}$ & $4.37 \pm 0.15^{\mathrm{bc}}$ & $0.41 \pm 0.02^{\mathrm{d}}$ & $5.05 \pm 0.23^{\mathrm{abc}}$ & $6.90 \pm 0.20^{\mathrm{a}}$ & $74.48 \pm 0.79^{f}$ & $5.08 \pm 0.08^{\mathrm{h}}$ \\
\hline Bhima Shubhra & $0.14 \pm 0.01^{b c}$ & $6.46 \pm 0.47^{\mathrm{a}}$ & $3.93 \pm 0.15^{\mathrm{a}}$ & $0.30 \pm 0.02^{\mathrm{a}}$ & $5.49 \pm 0.49^{\mathrm{bcd}}$ & $7.83 \pm$ & $75.89 \pm 0.20^{\mathrm{g}}$ & n.d. \\
\hline Hissar-2 & $0.30 \pm 0.01^{\mathrm{f}}$ & $10.76 \pm 0.67^{\mathrm{de}}$ & $5.40 \pm 0.20^{\mathrm{ef}}$ & $0.45 \pm 0.05^{\mathrm{de}}$ & $5.07 \pm 0.15^{\mathrm{abc}}$ & $10.93 \pm 0.15^{\mathrm{fg}}$ & $67.39 \pm 0.79^{\mathrm{b}}$ & $6.72 \pm 0.17^{1}$ \\
\hline Hissar-3 & $0.21 \pm 0.02^{\mathrm{de}}$ & $8.88 \pm 0.29^{\mathrm{bc}}$ & $4.43 \pm 0.21^{\mathrm{c}}$ & $0.41 \pm 0.02^{\mathrm{cd}}$ & $7.03 \pm 0.43^{\mathrm{f}}$ & $10.07 \pm 0.15^{\mathrm{d}}$ & $69.81 \pm 0.34^{\mathrm{cd}}$ & $5.68 \pm 0.21^{j}$ \\
\hline NHR & $0.17 \pm$ & $8.76 \pm 1.24^{\mathrm{bc}}$ & $5.97 \pm 0.15^{\mathrm{h}}$ & $0.43 \pm 0.03^{\mathrm{de}}$ & $8.28 \pm 0.20^{\mathrm{g}}$ & & & $8.63 \pm 0.17^{\mathrm{m}}$ \\
\hline Phursungi Local & $0.24 \pm 0.04^{\mathrm{e}}$ & $9.87 \pm$ & $4.30 \pm$ & $0.43 \pm$ & $26^{\mathrm{ab}}$ & & & $0.17^{\mathrm{i}}$ \\
\hline Pusa Madhavi & $0.40 \pm 0.01^{\mathrm{h}}$ & $13.23 \pm 0.90^{\mathrm{f}}$ & $4.10 \pm 0.10^{\mathrm{abc}}$ & $0.36 \pm 0.02^{\mathrm{b}}$ & $4.45 \pm 0.44^{\mathrm{a}}$ & $10.85 \pm 0.71^{\mathrm{ef}}$ & $67.02 \pm 0.73^{\mathrm{b}}$ & $6.11 \pm 0.04^{\mathrm{k}}$ \\
\hline Pusa red & $0.09 \pm 0.02^{\mathrm{a}}$ & $10.33 \pm 0.95^{\mathrm{de}}$ & $4.03 \pm 0.15^{\mathrm{ab}}$ & $0.47 \pm 0.02^{\mathrm{e}}$ & $5.67 \pm 0.42^{\mathrm{cd}}$ & $8.88 \pm 0.69^{c}$ & $70.62 \pm 1.63^{\mathrm{de}}$ & $2.61 \pm 0.14^{\mathrm{b}}$ \\
\hline Pusa Riddhi & 0.16 & $6.27 \pm 0.56^{\mathrm{a}}$ & $4.80 \pm$ & $0.36 \pm$ & $0.81^{\mathrm{abc}}$ & $6.88 \pm$ & $76.66 \pm 0.56^{\mathrm{g}}$ & $3.82 \pm 0.06^{\mathrm{e}}$ \\
\hline Sukhsagar & 0.13 & $9.98 \pm 0.11^{\mathrm{cd}}$ & $5.60 \pm 0.20^{\mathrm{fg}}$ & $0.33 \pm 0.03^{\mathrm{ab}}$ & $6.17 \pm 0.31^{\mathrm{de}}$ & $10.18 \pm 0.31^{\mathrm{de}}$ & $67.74 \pm 0.53^{\mathrm{bc}}$ & $4.15 \pm 0.04^{\mathrm{f}}$ \\
\hline Udaipur Local & $0.18 \pm 0.01^{\mathrm{cd}}$ & $6.76 \pm 0.43^{\mathrm{a}}$ & $3.90 \pm 0.10^{\mathrm{a}}$ & $0.31 \pm 0.02^{\mathrm{a}}$ & $4.57 \pm 0.35^{\mathrm{a}}$ & $8.03 \pm 0.15^{\mathrm{b}}$ & $76.43 \pm 0.69^{\mathrm{g}}$ & n.d. \\
\hline
\end{tabular}

Values are mean \pm standard deviation $(n=3)$. Values with different superscripts ${ }^{a h}$ in the same column are significantly different $(p \leq 0.05)$ by Duncan's multiple range test.

However, sulphur is an integrated part of ACSOs (S-alk(en) yl-L-cysteine sulfoxides), which are onion flavor precursors, but in various studies, no correlation was reported between the concentration of flavor precursors and total sulphur content, which revealed that there was a poor correlation between pungency and sulphur accumulation. The percentage of S-ACSOs in total sulphur content showed an increasing pattern from the outer section to the inner section of the skin; however, brown outer skin contained almost $30 \%$ of the total sulphur content in flavor precursors [12]. Benitez et al. [12] found the lowest flavor precursors in brown skin compared to onion bulb. On the other hand, Sarkar et al. [24] reported $0.44 \pm 0.01 \%$ of sulphur concentration in onion bulb produced by different mulching practices. It is already proven that mulching and other preharvest factors may affect sulphur content in onion bulb [25]. Concentration and ratio of flavor precursors differ from cultivar to cultivar and its ratio imparts peculiar aroma and taste to the onion.

3.2. Mineral Analysis. The mineral composition of onion skin powder of fifteen cultivars was determined on a dry weight basis. $\mathrm{K}, \mathrm{P}$, and $\mathrm{Ca}$ were recorded as principal abundant macrominerals in the outermost peel, ranging from $877.82 \pm 38.79$ to $3474.01 \pm 17.16 \mathrm{mg} / \mathrm{kg}, 796.22 \pm 13.01$ to $2873.10 \pm 46.76 \mathrm{mg} / \mathrm{kg}$, and $762.42 \pm 38.21$ to $3007.81 \pm 16.42 \mathrm{mg} / \mathrm{kg}$, respectively. The study revealed that cv. "NHRDF Red" contained the highest amount of macrominerals, such as $\mathrm{K} \quad(3474.01 \pm 17.16 \mathrm{mg} / \mathrm{kg})$, Ca $(3007.81 \pm 16.42 \mathrm{mg} / \mathrm{kg}), \mathrm{P}(2873.10 \pm 46.76 \mathrm{mg} / \mathrm{kg})$, and $\mathrm{Mg}$ $(1034.54 \pm 49.98 \mathrm{mg} / \mathrm{kg})$ among all the cultivars. The least amount of macronutrients was obtained in cv. "Bhima Shubhra" and "Udaipur Local" (Table 2). However, all cultivars were found to be a valuable source of important minerals according to the RDA of EFSA and FSSAI $[14,15]$.
According to FSSAI, RDA for women-men should be $3225-3750,600,600$, and $310-340 \mathrm{mg} / \mathrm{d}$ for $\mathrm{K}, \mathrm{P}, \mathrm{Ca}$, and $\mathrm{Mg}$, respectively (Table 2 ). The variation in mineral content of cultivars might be due to soil composition, harvesting time, and varietal differences.

Among the trace elements, $\mathrm{Fe}, \mathrm{Zn}$, and $\mathrm{Cu}$ were found in the highest concentration. They were quantified in the range of $\quad 110.60 \pm 0.37-211.96 \pm 0.08 \mathrm{mg} / \mathrm{kg}, \quad 17.95 \pm 0.06-39.27$ $\pm 0.34 \mathrm{mg} / \mathrm{kg}$, and $12.45 \pm 0.43-29.49 \pm 0.32 \mathrm{mg} / \mathrm{kg}$, respectively. Cultivar "NHRDF Red" was reported to have the highest concentration of trace elements among all the cultivars. The lowest concentration of trace elements was obtained in cv. "Bhima Shubhra." Cultivars "Agrifound Dark Red," "Bhima Shakti," "Hissar-2," "Hissar-3," "NHRDF Red," "Pusa Madhavi," and "Pusa Red" were found significantly different $(P \leq 0.05)$ from each other, whereas no significant $(p \leq 0.05)$ difference was obtained between cultivars "Agrifound Light Red," "Arka Kirthiman," "Bhima Kiran," "Bhima Shubhra," "Phursungi Local," and "Sukhsagar." A previous study showed a similar amount of macrominerals such as $\mathrm{K}(7297.88 \mathrm{mg} / \mathrm{kg}), \mathrm{P}(2491.04 \mathrm{mg} /$ $\mathrm{kg}), \mathrm{Ca}(1824.29 \mathrm{mg} / \mathrm{kg})$, and $\mathrm{Mg}(1990.59 \mathrm{mg} / \mathrm{kg})$ and $\mathrm{a}$ lower range for trace elements, that is, $\mathrm{Fe}(160.69 \mathrm{mg} / \mathrm{kg}), \mathrm{Al}$ (41.46 mg/kg), Zn (38.44 mg/kg), and $\mathrm{Cu}(27.23 \mathrm{mg} / \mathrm{kg})$ in onion bulb [26]. Chope and Terry [27] analyzed different cultivars of onion and obtained a greater range of macroelements, that is, $\mathrm{K} \quad(149.00-270.85 \mathrm{mg} / 100 \mathrm{~g}), \quad \mathrm{P}$ (15.92-29.25 mg/100 g), $\mathrm{Na}(3.84-14.57 \mathrm{mg} / 100 \mathrm{~g})$, and $\mathrm{Mg}$ $(6.39-10.81 \mathrm{mg} / 100 \mathrm{~g})$, while $\mathrm{Mn}(0.11-0.23 \mathrm{mg} / 100 \mathrm{~g})$ and $\mathrm{Zn}(0.27-0.45 \mathrm{mg} / 100 \mathrm{~g})$ were recorded in a lower concentration. Bello et al. [28] analyzed onion bulbs and found a good concentration of $\mathrm{K}(2.98 \mathrm{mg} / 100 \mathrm{~g})$, Ca $(1.22 \mathrm{mg} /$ $100 \mathrm{~g}), \mathrm{Mn}(0.05 \mathrm{mg} / 100 \mathrm{~g})$, Fe $(0.04 \mathrm{mg} / 100 \mathrm{~g})$, and $\mathrm{Cu}$ $(0.13 \mathrm{mg} / 100 \mathrm{~g})$ but lower than skin because onion skin contains a concentrated amount of minerals compared to bulb due to the absence of water. Likewise, Sarkar et al. [24] 


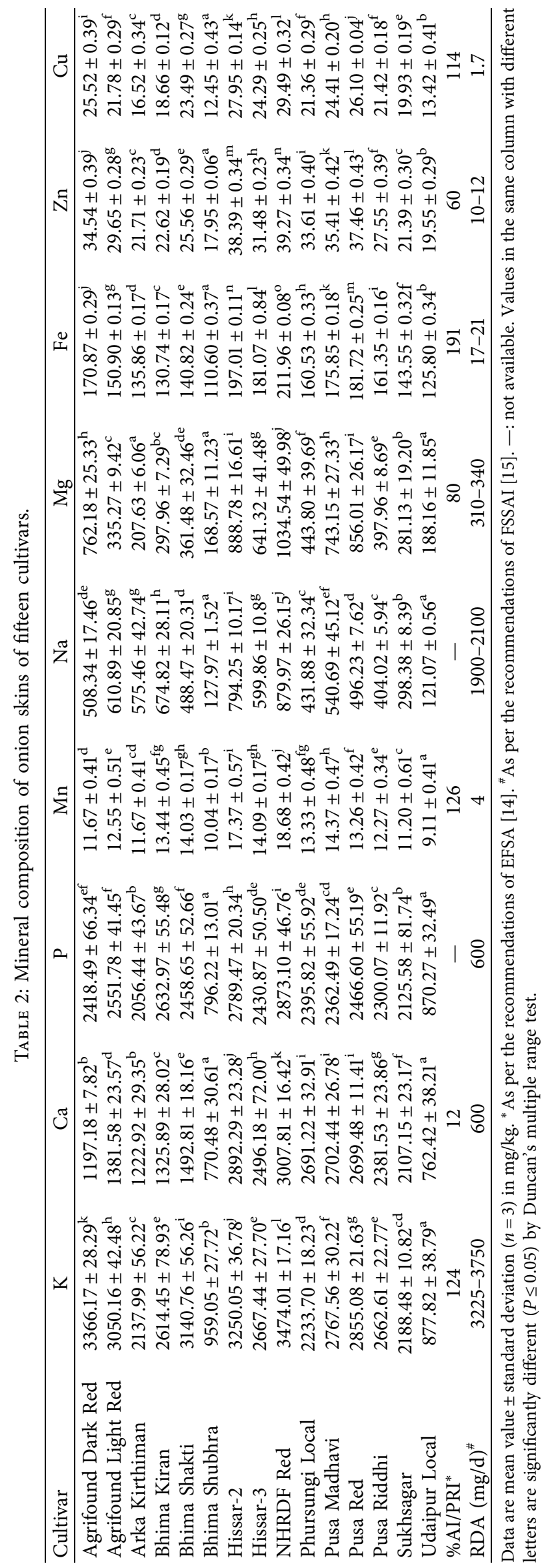


reported $1.10,0.29$, and $0.26 \mathrm{mg} / 100 \mathrm{~g}$ concentrations of $\mathrm{K}$, $\mathrm{P}$, and $\mathrm{Ca}$ in onion bulb cultivated by different mulching techniques, respectively. It showed that intrinsic and extrinsic factors influence the level of minerals. In Japan, onion bulbs from five major growing areas were investigated and a higher range of $\mathrm{Na}(107 \pm 45-343 \pm 221 \mu \mathrm{g} / \mathrm{g}), \mathrm{P}(2530 \pm$ $423-3120 \pm 498 \mu \mathrm{g} / \mathrm{g})$, and $\mathrm{Mg}(798 \pm 131-948 \pm 209 \mu \mathrm{g} / \mathrm{g})$ was reported. Moreover, Ariyama et al. [29] analyzed Japanese onions for $\mathrm{Zn}$ and quantified them in the range of $12.8 \pm 3.0-17.9 \pm 7.2 \mu \mathrm{g} / \mathrm{g}$. Geographical locations, cultivar types, and growing conditions play an important role in the mineral composition of the onion bulb and skin $[26,27]$.

3.3. Principal Component Analysis. PCA was performed to identify and visualize the association of the proximate composition and mineral composition in the fifteen onion cultivars that were considered for this study. The results of the PCA analysis of proximate composition showed that two PCs (Dim 1 and Dim2) could explain $68.6 \%$ of the variability in data (Figure 1(a)). The fat, ash, moisture content, and crude protein showed a positive correlation, while carbohydrate showed a negative correlation with all the other parameters. Moreover, an inverse correlation was also observed between fiber content and water activity. This result was expected since fibers can bind the water molecules within their complex matrix and reduce the overall vapor pressure, thereby preventing it from being detected by the water activity meter. It can also be noted that Udaipur Local, Bhima Shakti, Pusa Riddhi, and Bhima Shubhra have considerably higher carbohydrate content, while Hissar-3, Sukhsagar, Arka Kirthiman, and Agrifound Dark Red had higher fiber and crude protein.

Based on the biplot of the mineral composition (Figure 1(b)), it can be stated that the first principal component (Dim1) explained $100 \%$ of the variability in mineral data. The sodium, potassium, and phosphorus content exhibited a negative correlation with the iron, potassium, copper, and zinc content in the cultivars. This shows that the former set of mineral parameters could be a good indicator of the latter set and vice versa. However, the variation in the manganese content for the cultivars did not show any correlation to the other two mineral correlation sets and showed less variability ( $\operatorname{Dim} 2=0 \%)$. It should also be noted that the onion varieties that are clustered together show a similar mineral composition. For instance, the varieties Phursungi Local, Udaipur Local, Pusa Riddhi, and Sukhsagar would show homogeneous properties. Similarly, Pusa Madhavi, Bhima Shakti, NHRDF Red, and Hissar-3 would have a similar mineral composition. Another cluster that can be recognized consists of the Pusa Red, Arka Kirthiman, Bhima Kiran, and Bhima Shubhra varieties; however, the correlation between these varieties would be relatively less as compared to the other two identified clusters due to a more scattered cluster.

3.4. Functional Group Assessment. FTIR spectroscopy is the best-suited technique to investigate the probable chemical compounds or metabolites in samples. It is a nondestructive method of analysis, which saves the sample contents from mechanical or thermal energy [30]. In the present study, FTIR analysis of onion skin powder of fifteen cultivars confirmed the presence of various functional groups. Spectra of different cultivars are shown in Figure 2. Spectral bands between fingerprint regions from 1800 to $750 \mathrm{~cm}^{-1}$ reflect the primary biomolecules like protein, carbohydrate, lipid, nucleic acid, and polyphenols [31]. The skin powder of all the cultivars showed a strong and common absorbance between the wavelength of $1012-1009 \mathrm{~cm}^{-1}$ and $1607-1597 \mathrm{~cm}^{-1}$, while medium absorbance was obtained between the wave number of $1418-1317 \mathrm{~cm}^{-1}, \quad 2116-2113 \mathrm{~cm}^{-1}$, and $2917-2900 \mathrm{~cm}^{-1}$. The weak wavelength ranged from 1147 to $1100 \mathrm{~cm}^{-1}, 1245$ to $1237 \mathrm{~cm}^{-1}, 1878$ to $1849 \mathrm{~cm}^{-1}$, and 2342 to $2320 \mathrm{~cm}^{-1}$ in all the cultivars. Apart from this, other absorbance ranges were also observed in some cultivars between 840 and $804 \mathrm{~cm}^{-1}$ wavelengths. Both strong absorbances that fall between the wavelength of $1150-1000 \mathrm{~cm}^{-1}$ and $1615-1495 \mathrm{~cm}^{-1}$ are assigned to C-F stretch aliphatic organic halogen compounds and aromatic nitro compounds, respectively [32]. Medium peak frequencies fall between the range of $1420-1300 \mathrm{~cm}^{-1}$, $2140-2100 \mathrm{~cm}^{-1}$, and $2923-2915 \mathrm{~cm}^{-1}$, which showed the presence of carboxylate (carboxylic acid salt), $\mathrm{C} \equiv \mathrm{C}$ stretch terminal alkyne, and methylene in the saturated aliphatic group, respectively [33]. Weak frequencies between 1200 and $1100 \mathrm{~cm}^{-1}, 1850$ and $1650 \mathrm{~cm}^{-1}$, and 2363 and $2313 \mathrm{~cm}^{-1}$, respectively, represent sulfonates (sulphur oxy compounds), carbonyl compounds, and atmospheric $\mathrm{CO}_{2}$. The other captured peaks between 900 and $800 \mathrm{~cm}^{-1}$ are assigned to the $\mathrm{C}-\mathrm{H}$ stretch of aromatic (aryl) ring frequency [31]. The study showed that all the cultivars exhibited a similar pattern of peaks; however, the peak sharpness (strong and medium) showed a difference in biomolecules level of onion due to varietal difference. Larrosa et al. [34] investigated vegetable paste and reported the presence of phenolic, aromatic, and carbonic groups. Characterization of red onion skin tannin represented almost the same peaks absorbance at $1650 \mathrm{~cm}^{-1}, 1437 \mathrm{~cm}^{-1}$, and $1115 \mathrm{~cm}^{-1}$ [35]. Moreover, the FTIR study of onion powder showed the presence of starch and other important compounds between the wavenumbers of $4000-650 \mathrm{~cm}^{-1}$, which supports the present study [36].

3.5. Thermal Characterization. The thermal decomposition analysis was carried out by TGA for the detection of mass change/loss of samples. TGA curves are shown in Figure 3. Thermograms of TGA showed that the highest mass loss (25.31\%) was reported in cv. "Phursungi Local" (Figure 3). A total $1.91 \%$ residual mass was obtained for "Phursungi Local." The least mass decomposition (0.64\%) was observed in cv. "Agrifound Dark Red" between the temperature ranges of $220^{\circ} \mathrm{C}-270^{\circ} \mathrm{C}$ with the residual mass of $70.98 \%$. The maximum mass loss and total residual mass of each cultivar are presented in Table 3. A significant $(p \leq 0.05)$ difference was obtained between cultivars. Mass loss at the first step was probably due to the evaporation of available water. 


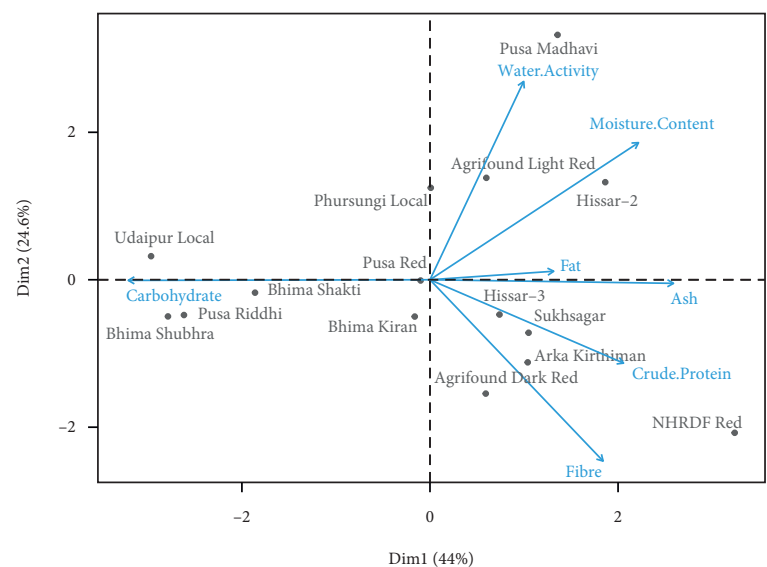

(a)

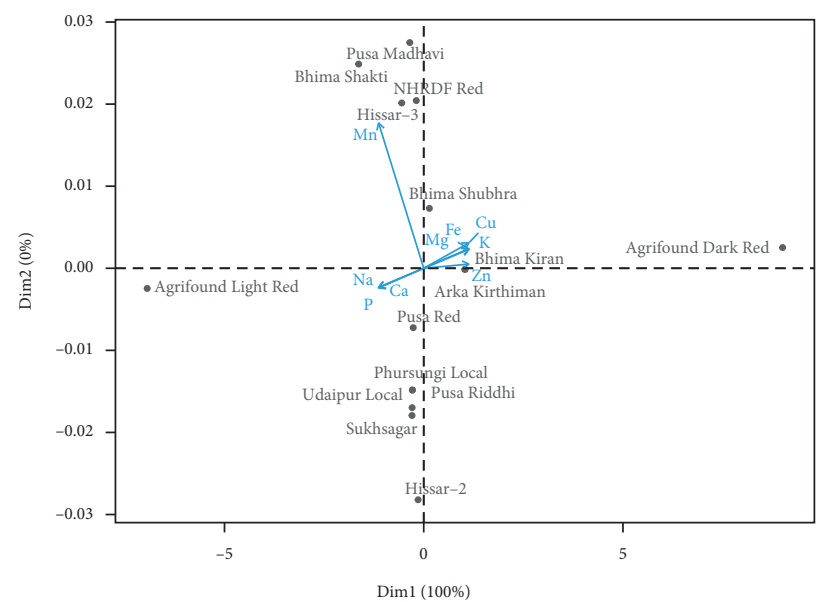

(b)

Figure 1: Principal Component Analysis biplots for (a) proximate composition and (b) mineral content.



Figure 2: IR spectra of onion skin powder of fifteen cultivars: 1, Agrifound Dark Red; 2, Agrifound Light Red; 3, Arka Kirthiman; 4, Bhima Kiran; 5, Bhima Shakti; 6, Bhima Shubhra; 7, Hissar-2; 8, Hissar-3; 9, NHRDF Red; 10, Phursungi Local; 11, Pusa Madhavi; 12, Pusa Red; 13, Pusa Riddhi; 14, Sukhsagar; 15, Udaipur Local.

At the other decomposition steps, the mass loss occurred probably because of different components such as secondary metabolites and carbohydrates [37]. At the end of the experiment $\left(299.9^{\circ} \mathrm{C}\right)$, the lowest residual mass with $1.91 \%$ was found in cv. "Phursungi Local," while the highest residual mass was obtained in cv. "Agrifound Dark Red" with 70.98\% Table 3. To the best of our knowledge, previous studies are not available on the thermal attributes of onion skin powder. However, a TGA study of the powder of guava, sapota, and papaya showed the maximum mass loss from $30 \%$ to $41.45 \%$ between combined temperature ranges of $132^{\circ} \mathrm{C}-332^{\circ} \mathrm{C}[36]$, which supports the findings of the present investigation. Moreover, the thermal analysis of the extract of Syzygium cumini L. leaves also revealed a significant mass loss (28.16\%) between the temperature range of $209^{\circ} \mathrm{C}-260^{\circ} \mathrm{C}$ [38]. Different concentrations of crude fiber, ash, and protein are the main reasons for differences among residual masses of different cultivars. TGA revealed "Phursungi Local" as the least thermally stable cultivar and "Agrifound Dark Red" as the best thermally stable cultivar which explores that the onion skin powder of cv. "Agrifound Dark Red" can be utilized for higher temperature processes.

DSC curves explored the phase change and glass transition temperature $(\mathrm{Tg})$ of onion skin powder of fifteen cultivars. DSC curves are given in Figure 4 and $\mathrm{Tg}$ for all the cultivars is given in Table 4. The cv. "Agrifound Dark Red" had a $\mathrm{Tg}$ temperature between $64.4^{\circ} \mathrm{C}$ and $90.6^{\circ} \mathrm{C}$. It also showed a single endothermic peak at $102.1^{\circ} \mathrm{C}$ (Figure 4). "Agrifound Light Red" showed the $\mathrm{Tg}$ between $135.9^{\circ} \mathrm{C}$ and $140.9^{\circ} \mathrm{C}$. It also showed two endothermic peaks: the first huge at $160.4^{\circ} \mathrm{C}$ and the second small peak at $244^{\circ} \mathrm{C}$. The $\mathrm{Tg}$ temperature for cv. "Arka Kirthiman" was recorded between the temperature ranges of $111.1^{\circ} \mathrm{C}-132.7^{\circ} \mathrm{C}$. The $\mathrm{Tg}$ of $\mathrm{cv}$. "NHRDF Red" was found between $120.2^{\circ} \mathrm{C}$ and $124.5^{\circ} \mathrm{C}$ and 


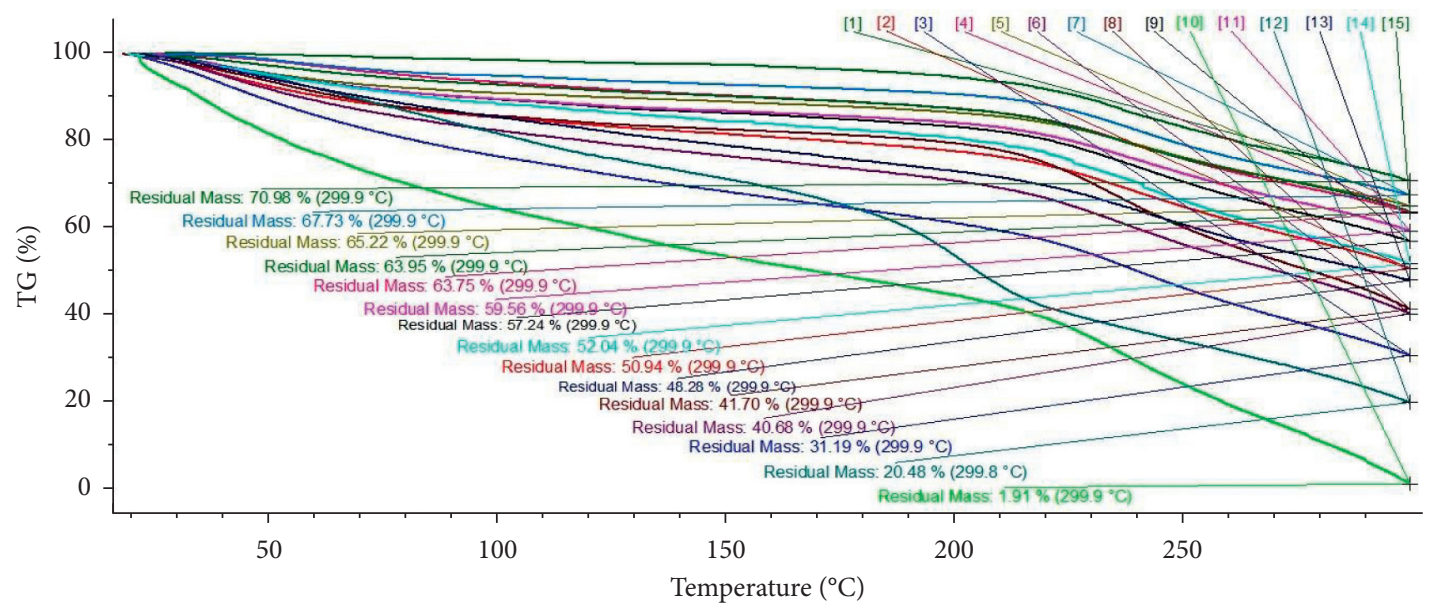

FIGURE 3: Combined thermogravimetric curves of onion skin powder of fifteen cultivars exploring gradual mass loss: 1, Agrifound Dark Red; 2, Agrifound Light Red; 3, Arka Kirthiman; 4, Bhima Kiran; 5, Bhima Shakti; 6, Bhima Shubhra; 7, Hissar-2; 8, Hissar-3; 9, NHRDF Red; 10, Phursungi Local; 11, Pusa Madhavi; 12, Pusa Red; 13, Pusa Riddhi; 14, Sukhsagar; 15, Udaipur Local.

Table 3: Maximum mass loss (with respect to the temperature) and residual mass of onion skin powder of fifteen cultivars.

\begin{tabular}{|c|c|c|c|}
\hline Cultivar & Maximum mass loss (\%) & Temperature range $\left({ }^{\circ} \mathrm{C}\right)$ & Residual mass (\%) at $299^{\circ} \mathrm{C}$ \\
\hline Agrifound Dark Red & $12.80 \pm 0.05^{\mathrm{b}}$ & $220-270$ & $70.98 \pm 0.04^{\mathrm{m}}$ \\
\hline Agrifound Light Red & $12.25 \pm 0.08^{\mathrm{b}}$ & $240-290$ & $50.90 \pm 0.06^{\mathrm{f}}$ \\
\hline Arka Kirthiman & $17.16 \pm 0.07^{\mathrm{ef}}$ & $220-270$ & $31.19 \pm 0.02^{c}$ \\
\hline Bhima Kiran & $13.14 \pm 0.05^{\mathrm{c}}$ & $220-270$ & $63.75 \pm 0.05^{\mathrm{j}}$ \\
\hline Bhima Shakti & $12.55 \pm 0.09^{\mathrm{b}}$ & $220-270$ & $65.22 \pm 0.05^{\mathrm{k}}$ \\
\hline Bhima Shubhra & $16.47 \pm 0.03^{\mathrm{e}}$ & $220-270$ & $40.68 \pm 0.04^{\mathrm{d}}$ \\
\hline Hissar-2 & $11.07 \pm 0.02^{\mathrm{a}}$ & $220-270$ & $67.73 \pm 0.07^{1}$ \\
\hline Hissar-3 & $22.16 \pm 0.05^{\mathrm{g}}$ & $220-270$ & $41.70 \pm 0.02^{\mathrm{d}}$ \\
\hline NHRDF Red & $15.27 \pm 0.04^{\mathrm{d}}$ & $220-270$ & $57.24 \pm 0.02^{\mathrm{h}}$ \\
\hline Phursungi Local & $25.31 \pm 0.10^{\mathrm{h}}$ & $220-270$ & $1.91 \pm 0.08^{\mathrm{a}}$ \\
\hline Pusa Madhavi & $11.32 \pm 0.06^{\mathrm{ab}}$ & $250-299$ & $59.56 \pm 0.03^{\mathrm{i}}$ \\
\hline Pusa Red & $22.72 \pm 0.04^{\mathrm{g}}$ & $220-270$ & $28.70 \pm 0.04^{\mathrm{b}}$ \\
\hline Pusa Riddhi & $13.08 \pm 0.05^{\mathrm{c}}$ & $220-270$ & $48.28 \pm 0.01^{\mathrm{e}}$ \\
\hline Sukhsagar & $17.02 \pm 0.02^{\mathrm{ef}}$ & $220-270$ & $52.04 \pm 0.03^{\mathrm{fg}}$ \\
\hline Udaipur Local & $10.67 \pm 0.06^{\mathrm{a}}$ & $220-270$ & $63.95 \pm 0.04^{j}$ \\
\hline
\end{tabular}

Data are mean value \pm standard deviation $(n=3)$. Values in the same column with different letters are significantly different $(P \leq 0.05)$ by Duncan's multiple range test.

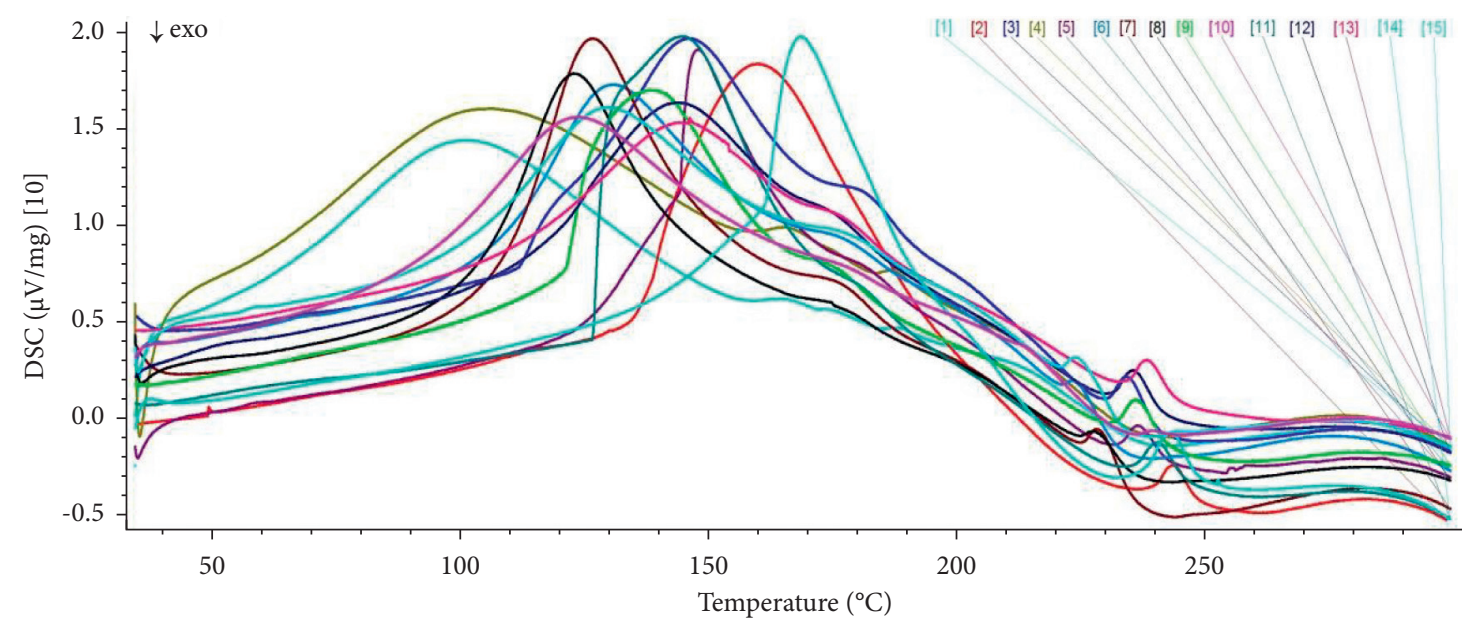

Figure 4: Combined differential scanning calorimetry curve of onion skin powder of fifteen cultivars: 1, Agrifound Dark Red; 2 , Agrifound Light Red; 3, Arka Kirthiman; 4, Bhima Kiran; 5, Bhima Shakti; 6, Bhima Shubhra; 7, Hissar-2; 8, Hissar-3; 9, NHRDF Red; 10, Phursungi Local; 11, Pusa Madhavi; 12, Pusa Red; 13, Pusa Riddhi; 14, Sukhsagar; 15, Udaipur Local. 
TABLE 4: Glass transition temperature ( $\mathrm{Tg}$ ) of onion skin powder of fifteen cultivars.

\begin{tabular}{lccc}
\hline Cultivar & $\begin{array}{c}\text { Glass transition }(\mathrm{Tg}) \text { temperature } \\
\left.\text { (onset }{ }^{\circ} \mathrm{C}-\mathrm{end}^{\circ} \mathrm{C}\right)\end{array}$ & $\begin{array}{c}\text { Temperature of first endothermic } \\
\text { peak }\left({ }^{\circ} \mathrm{C}\right)\end{array}$ & $\begin{array}{c}\text { Temperature of second } \\
\text { endothermic peak }\left({ }^{\circ} \mathrm{C}\right)\end{array}$ \\
\hline Agrifound Dark Red & $64.4-90.6$ & $102.1 \pm 0.02^{\mathrm{a}}$ & - \\
Agrifound Light Red & $135.9-140.9$ & $160.4 \pm 0.04^{\mathrm{j}}$ & $244.0 \pm 0.09^{\mathrm{h}}$ \\
Arka Kirthiman & $11.1-132.7$ & $146.5 \pm 0.03^{\mathrm{h}}$ & $234.5 \pm 0.10^{\mathrm{c}}$ \\
Bhima Kiran & $65.7-106.9$ & $106.7 \pm 0.05^{\mathrm{b}}$ & - \\
Bhima Shakti & $143.3-144.5$ & $148.4 \pm 0.05^{\mathrm{i}}$ & $238.5 \pm 0.08^{\mathrm{e}}$ \\
Bhima Shubhra & $107.5-127.3$ & $131.0 \pm 0.03^{\mathrm{e}}$ & $223.7 \pm 0.11^{\mathrm{a}}$ \\
Hissar-2 & $107.0-110.2$ & $127.0 \pm 0.06^{\mathrm{d}}$ & $228.8 \pm 0.13^{\mathrm{b}}$ \\
Hissar-3 & $103.6-114.4$ & $123.3 \pm 0.04^{\mathrm{c}}$ & $228.1 \pm 0.09^{\mathrm{b}}$ \\
NHRDF Red & $120.2-124.5$ & $138.7 \pm 0.06^{\mathrm{f}}$ & $236.4 \pm 0.14^{\mathrm{d}}$ \\
Phursungi Local & $94.2-118.9$ & $124.0 \pm 0.02^{\mathrm{c}}$ & - \\
Pusa Madhavi & $127.2-128.6$ & $144.7 \pm 0.04^{\mathrm{g}}$ & $240.7 \pm 0.08^{\mathrm{f}}$ \\
Pusa Red & $114.6-131.9$ & $144.3 \pm 0.03^{\mathrm{g}}$ & $236.0 \pm 0.11^{\mathrm{d}}$ \\
Pusa Riddhi & $146.4-146.8$ & $146.6 \pm 0.02^{\mathrm{h}}$ & $238.8 \pm 0.16^{\mathrm{e}}$ \\
Sukhsagar & $158.2-159.8$ & $169.0 \pm 0.03^{\mathrm{k}}$ & $243.7 \pm 0.12^{\mathrm{g}}$ \\
Udaipur Local & $101.7-128.1$ & $130.5 \pm 0.06^{\mathrm{e}}$ & $224.1 \pm 0.09^{\mathrm{a}}$ \\
\hline
\end{tabular}

“-" no peak found. Data are mean value \pm standard deviation $(n=3)$. Values in the same column with different letters are significantly different $(p \leq 0.05)$ by Duncan's multiple range test.

one huge and second small endothermic peaks occurred at 138.7 and $236.4^{\circ} \mathrm{C}$, respectively.

The study of cv. "Pusa Madhavi" revealed that the Tg was taken place between the temperature range of $127.2^{\circ} \mathrm{C}-128.6^{\circ} \mathrm{C}$. Two endothermic peaks were also obtained at different temperatures, one huge peak at $144.7^{\circ} \mathrm{C}$ and the second tiny peak at $240.7^{\circ} \mathrm{C}$. Moderate ranges of $\mathrm{Tg}$ (phase changing), that is, $111.1^{\circ} \mathrm{C}-132.7^{\circ} \mathrm{C}$, $107.5^{\circ} \mathrm{C}-127.3^{\circ} \mathrm{C}, 107.0^{\circ} \mathrm{C}-110.2^{\circ} \mathrm{C}, 103.6^{\circ} \mathrm{C}-114.4^{\circ} \mathrm{C}$, and $101.7^{\circ} \mathrm{C}-128.1^{\circ} \mathrm{C}$, were obtained, respectively, for "Arka Kirthiman," "Bhima Shubhra," "Hissar-2," "Hissar-3," and "Udaipur Local" cultivars and a significant $(p \leq 0.05)$ difference was observed between cultivars (Table 4). Possible occurred reactions were dehydroxylation, decarboxylation, and demethoxylation $[39,40]$. As per the study, the $\mathrm{Tg}$ temperature revealed that the earliest phase change was taken place in cv. "Agrifound Dark Red" between $64.4^{\circ} \mathrm{C}$ and $90.6^{\circ} \mathrm{C}$, while late phase change was confirmed in $\mathrm{cv}$. "Sukhsagar" between $158.2^{\circ} \mathrm{C}$ and $159.8^{\circ} \mathrm{C}$. Likewise, de Oliveira Cartaxo-Furtado et al. [38] studied the extract of Syzygium cumini L. leaves and found the largest endothermic peak between the temperature range of $114.2^{\circ} \mathrm{C}-150.69^{\circ} \mathrm{C}$. Similarly, Da Silva et al. [41] observed a thermal event at $120^{\circ} \mathrm{C}$ during the analysis of freeze-dried camu camu fruit pulp (Myrciaria dubia). Apart from this, many endothermic peaks were obtained between $126.14^{\circ} \mathrm{C}$ and $325.50^{\circ} \mathrm{C}$ in the analysis of the dried extract of Schinopsis brasiliensis Engl. [30].

\section{Conclusions}

In the present study, the skins of fifteen onion cultivars were investigated for various important parameters. The physicochemical analysis explored that "NHRDF Red" has the highest protein, fiber, and ash content among the cultivars studied, whereas "Pusa Riddhi" and "Pusa Red" were revealed as the best source of carbohydrates and fat among all the cultivars. Additionally, sulphur and mineral analysis showed OSP as a rich source of essential minerals. TGA studies confirmed that cv. "Pusa Madhavi" was the most thermally stable, while "Pusa Red" was reported as the least thermally stable compare to others and DSC confirmed the earliest phase change in cv. "Agrifound Dark Red" but late phase change in cv. "Sukhsagar." FTIR analysis suggested that all the cultivars were rich in various functional groups, such as methylene in the saturated aliphatic group, aromatic ring, carbohydrate, and sulphur oxy compounds. Onion skin waste in processing industries may be utilized for various purposes like functional/nutraceutical food development, energy, and biogas production $[5-7,10]$.

\section{Data Availability}

All the data pertaining to this work have been provided within the text.

\section{Conflicts of Interest}

The authors declare no conflicts of interest with respect to this work.

\section{Authors' Contributions}

Narashans Alok Sagar and Sunil Pareek conceived the experiment(s); Narashans Alok Sagar contributed to investigation; Vikas contributed to data analysis and PCA application; Narashans Alok Sagar and Ayon Tarafdar were responsible for writing of the original draft; Sunil Pareek contributed to reviewing and editing, supervision, and project administration; Anil Khar contributed to resources and draft editing.

\section{Acknowledgments}

The authors are highly grateful to All India Coordinated Research Project on Onion and Garlic, Division of Vegetable 
Science, Indian Agricultural Research Institute, New Delhi, for providing the onion bulbs for the study. Dr. Khalid Bashir, Department of Basic and Applied Sciences, and Mr. Mayank Nigam, Mr. Naveen Roja, and Mr. Ankur Chaudhary, Laboratory In-Charge, National Institute of Food Technology Entrepreneurship and Management (NIFTEM), are also acknowledged for their extended help. The financial support provided by UGC to the first author vide letter no. F.15-6(DEC.2018)/2019(NET) is highly acknowledged.

\section{References}

[1] FAO, "Onion production data," Food and Agriculture Organization of the United Nations, 2021, http://www.fao.org/ faostat/en/\#data/QC/visualize.

[2] U. Gawlik-Dziki, K. Kaszuba, K. Piwowarczyk, M. Świeca, D. Dziki, and J. Czyż, "Onion skin - raw material for the production of supplement that enhances the health-beneficial properties of wheat bread," Food Research International, vol. 73, pp. 97-106, 2015.

[3] N. Memon, Y. Gat, S. Arya, and R. Waghmare, "Combined effect of chemical preservative and different doses of irradiation on green onions to enhance shelf life," Journal of the Saudi Society of Agricultural Sciences, vol. 19, no. 3, pp. 207-215, 2020.

[4] N. A. Sagar, S. Pareek, S. Sharma, E. M. Yahia, and M. G. Lobo, "Fruit and vegetable waste: bioactive compounds, their extraction, and possible utilization," Comprehensive Reviews in Food Science and Food Safety, vol. 17, no. 3, pp. 512-531, 2018.

[5] N. A. Sagar, S. Pareek, and G. A. Gonzalez-Aguilar, "Quantification of flavonoids, total phenols and antioxidant properties of onion skin: a comparative study of fifteen Indian cultivars," Journal of Food Science \& Technology, vol. 57, no. 7, pp. 2423-2432, 2020.

[6] N. A. Sagar, S. Tarafdar, S. Agarwal, A. Tarafdar, and S. Sharma, "Polyamines: functions, metabolism, and role in human disease management," Medical Science, vol. 9, no. 2, p. 44, 2021.

[7] N.-A. Sagar and S. Pareek, "Dough rheology, antioxidants, textural, physicochemical characteristics, and sensory quality of pizza base enriched with onion (Allium cepa L.) skin powder," Scientific Reports, vol. 10, pp. 1-11, 2020.

[8] D. Dziki, R. Różyło, U. Gawlik-Dziki, and M. Świeca, "Current trends in the enhancement of antioxidant activity of wheat bread by the addition of plant materials rich in phenolic compounds," Trends in Food Science \& Technology, vol. 40, no. 1, pp. $48-61,2014$.

[9] B. Adhikari, S. K. Dhungana, M. Adhikari, I.-D. Kim, and D.-H. Shin, "Antioxidant activities, polyphenol, flavonoid, and amino acid contents in peanut shell," Journal of the Saudi Society of Agricultural Sciences, vol. 18, no. 4, pp. 437-442, 2019.

[10] B. Patel and B. Gami, "Biomass characterization and its use as solid fuel for combustion," Iranian Journal of Energy and Environment, vol. 3, pp. 123-128, 2012.

[11] AOAC, Official Methods of Analysis, Association of Official Analytical Chemists, Washington, DC, 2016.

[12] V. Benítez, E. Mollá, M. A. Martín-Cabrejas et al., "Characterization of industrial onion wastes (Allium cepa L.): dietary fibre and bioactive compounds," Plant Foods for Human Nutrition, vol. 66, no. 1, pp. 48-57, 2011.
[13] R. Sirohi and J. P. Pandey, "Dilute acid hydrolysis of spoiled wheat grains: analysis of chemical, rheological and spectral characteristics," Bioresource Technology, vol. 283, pp. 53-58, 2019.

[14] FSSAI, "Daily allowance (RDA)," Food Safety and Standards Authority of India (FSSAI), 2020, https://www.fssai.gov.in/ upload/advisories/2020/01/5e159e0a809bbLetter_RDA_08_ 01_2020.pdf.

[15] EFSA, "(Dietary reference values for nutrients summary report," European Food Safety Authority, vol. 14, Article ID e15121, 2017.

[16] Y. Kumar, A. Tarafdar, D. Kumar, and P. C. Badgujar, "Effect of Indian brown seaweed Sargassum wightii as a functional ingredient on the phytochemical content and antioxidant activity of coffee beverage," Journal of Food Science \& Technology, vol. 56, no. 10, pp. 4516-4525, 2019.

[17] R. Sirohi, J. P. Pandey, A. Tarafdar, A. Agarwal, S. K. Chaudhuri, and R. Sindhu, "An environmentally sustainable green process for the utilization of damaged wheat grains for poly-3-hydroxybutyrate production," Environmental Technology \& Innovation, vol. 21, Article ID 101271, 2021.

[18] R. S. Rapusas and R. H. Driscoll, "Thermophysical properties of fresh and dried white onion slices," Journal of Food Engineering, vol. 24, no. 2, pp. 149-164, 1995.

[19] A.-M. S. Ismail, H. I. Abo-Elmagd, and M. M. Housseiny, "A safe potential juice clarifying pectinase from Trichoderma viride EF-8 utilizing Egyptian onion skins," Journal of Genetic Engineering and Biotechnology, vol. 14, no. 1, pp. 153-159, 2016.

[20] G. S. Pereira, M. Cipriani, E. Wisbeck, O. Souza, J. O. Strapazzon, and R. M. M. Gern, "Onion juice waste for production of Pleurotus sajor-caju and pectinases," Food and Bioproducts Processing, vol. 106, pp. 11-18, 2017.

[21] A. Tarafdar, N. C. Shahi, and A. Singh, "Freeze-drying behaviour prediction of button mushrooms using artificial neural network and comparison with semi-empirical models," Neural Computing \& Applications, vol. 31, no. 11, pp. 72577268, 2019.

[22] I.-S. Choi, E.-J. Cho, J.-H. Moon, and H.-J. Bae, “Onion skin waste as a valorization resource for the by-products quercetin and biosugar," Food Chemistry, vol. 188, pp. 537-542, 2018.

[23] I. Majid, B. N. Dar, and V. Nanda, "Rheological, thermal, micro structural and functional properties of freeze dried onion powders as affected by sprouting," Food Bioscience, vol. 22, pp. 105-112, 2018.

[24] M. D. Sarkar, A. H. M. Solaiman, M. S. Jahan, R. N. Rojoni, K. Kabir, and M. Hasanuzzaman, "Soil parameters, onion growth, physiology, biochemical and mineral nutrient composition in response to colored polythene film mulches," Annals of Agricultural Science, vol. 64, no. 1, pp. 63-70, 2019.

[25] A. M. Abu-Rayyan and B. E. Abu-Irmaileh, "Onion development and yield in response to manual cultivation, herbicides, or colored mulches," Journal of Vegetable Crop Production, vol. 10, no. 1, pp. 37-49, 2004.

[26] B.-A. Akinwande and S.-J. Olatunde, "Comparative evaluation of the mineral profile and other selected components of onion and garlic," International Food Research Journal, vol. 22, no. 1, pp. 1-9, 2015.

[27] G.-A. Chope and L.-A. Terry, "Use of canonical variate analysis to differentiate onion cultivars by mineral content as measured by ICP-AES," Food Chemistry, vol. 115, no. 3, pp. 1108-1113, 2003. 
[28] M.-O. Bello, I.-O. OlabanjiAbdul-Hammed, and T.-D. Okunade, "Characterization of domestic onion wastes and bulb (Allium cepa L.): fatty acids and metal contents," International Food Research Journal, vol. 20, pp. 2153-2159, 2013.

[29] K. Ariyama, Y. Aoyama, A. Mochizuki, Y. Homura, M. Kadokura, and A. Yasui, "Determination of the geographic origin of onions between three main production areas in Japan and other countries by mineral composition," Journal of Agricultural and Food Chemistry, vol. 55, no. 2, pp. 347-354, 2007.

[30] F. H. A. Fernandes, C. P. Santana, R. L. Santos et al., "Thermal characterization of dried extract of medicinal plant by DSC and analytical techniques," Journal of Thermal Analysis and Calorimetry, vol. 113, no. 2, pp. 443-447, 2013.

[31] X. Lu, J. Wang, H. M. Al-Qadiri et al., "Determination of total phenolic content and antioxidant capacity of onion (Allium cepa) and shallot (Allium oschaninii) using infrared spectroscopy," Food Chemistry, vol. 129, no. 2, pp. 637-644, 2011.

[32] Coates, "Interpretation of infrared spectra, a practical approach," Encyclopedia of Analytical Chemistry, pp. 1081510837, John Wiley \& Sons, Chichester, UK, 2000.

[33] N.-J.-N. Nnaji, C.-O.-B. Okoye, N.-O. Obi-Egbedi et al., "Spectroscopic characterization of red onion skin tannin and it's use as alternative aluminium corrosion inhibitor in hydrochloric acid solutions," International Journal of Electrochemical Science, vol. 8, pp. 1735-1758, 2013.

[34] A. P. Q. Larrosa, T. R. S. Cadaval, and L. A. A. Pinto, "Influence of drying methods on the characteristics of a vegetable paste formulated by linear programming maximizing antioxidant activity," Lebensmittel-Wissenschaft und -Technologie- Food Science and Technology, vol. 60, no. 1, pp. 178-185, 2015.

[35] W.-H. Su and D.-W. Sun, "Fourier transform infrared and Raman and hyperspectral imaging techniques for quality determinations of powdery foods: a review," Comprehensive Reviews in Food Science and Food Safety, vol. 17, no. 1, pp. 104-122, 2018.

[36] K. A. Athmaselvi, C. Kumar, M. Balasubramanian, and I. Roy, "Thermal, structural, and physical properties of freeze dried tropical fruit powder," Journal of Food Processing, vol. 2014, pp. 1-10, Article ID 524705, 2014.

[37] X. Song, H. Hu, and B. Zhang, "Drying characteristics of Chinese Yam (Dioscorea opposita Thunb) by far-infrared radiation and heat pump," Journal of the Saudi Society of Agricultural Sciences, vol. 17, no. 3, pp. 290-296, 2018.

[38] N. A. d. O. Cartaxo-Furtado, A. R. F. de Castilho, I. A. Freires et al., "Physicochemical characterization of a new raw material obtained from leaves of Syzygium cumini (L.) Skeel (Myrtaceae)," Journal of Thermal Analysis and Calorimetry, vol. 127, no. 2, pp. 1137-1141, 2017.

[39] N. A. Afoakwah, Y. Dong, Y. Zhao et al., "Characterization of Jerusalem artichoke (Helianthus tuberosus L.) powder and its application in emulsion-type sausage," Lebensmittel-Wissenschaft und-Technologie- Food Science and Technology, vol. 64, no. 1, pp. 74-81, 2015.

[40] C. Osorio, J.-G. Carriazo, and H. Barbosa, "Thermal and structural study of guava (Psidium guajava L.) powders obtained by two dehydration methods," Quím. Nova, vol. 34, pp. 636-640, 2001.

[41] M. A. Da Silva, P. J. A. Sobral, and T. G. Kieckbusch, "Water sorption and glass transition of freeze-dried camu-camu (myrciaria dubia (H.B.K.) Mc Vaugh) pulp," Journal of Thermal Analysis and Calorimetry, vol. 84, no. 2, pp. 435-439, 2006. 